CURRENT RESEARCH JOURNAL OF PEDAGOGICS

(ISSN -2767-3278)

VOLUME 03 ISSUE 01 Pages: 67-74

SJIF IMPACT FACTOR (2021: 5 • 714)

OCLC - 1242041055 METADATA IF - 8.145

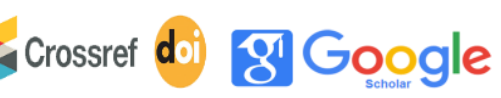

14. netnD

metapata (5) WorldCat ${ }^{\circ}$ f̂l MENDELEY

Publisher: Master Journals

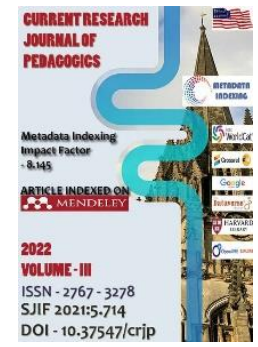

Journal Website: https://masterjournals. com/index.php/crip

Copyright: Original content from this work may be used under the terms of the creative commons attributes 4.0 licence.
Research Article

\section{SOME ASPECTS OF THE POLICY OF RELOCATION IN ANDIJAN REGION}

Submission Date: January 07, 2022, Accepted Date: January 20, 2022, Published Date: January 30, 2022

Crossref doi: https://doi.org/10.37547/pedagogics-crjp-03-01-11

Bekhzod B. Abbasov

Lecture, Department of “Archival Studies” Namangan State University, Uzbekistan

\title{
ABSTRACT
}

After the Second World War, the issues of irrigation and melioration in the Fergana Valley, as well as the resettlement of the population to newly mastered lands were analyzed and studied.

\section{KEYWORDS}

The cotton growing, irrigation, mileoration, land development, migration, cotton, reservoir, collector, sovkhozs, drain.

\section{INTRODUCTION}

Uzbekistan after the Second World War in the USSR and at the beginning of the 1950s, the issue of agricultural development was mainly of an ecstatic nature. But, nevertheless, in the socio-economic policy of the Soviet government and the leadership of the Republic, it was important, first of all, to master new lands, to conduct large-scale irrigation and melioration works, as well as to move the population to newly established collective farms and Soviets.It is worth noting that this process began after the end of the Second World War, in 1945-1947, tasks were set such as the completion of the appropriation of 260 thousand hectares of land and the improvement of the technical condition of the irrigation system. These works, that is, irrigation and melioration works, were associated with the development of additional new irrigated lands[1]. 
CURRENT RESEARCH JOURNAL OF PEDAGOGICS

(ISSN -2767-3278)

VOLUME 03 ISSUE 01 Pages: 67-74

SJIF IMPACT FACTOR (2021: 5. 714)

OCLC - 1242041055 METADATA IF - 8.145

Crossref
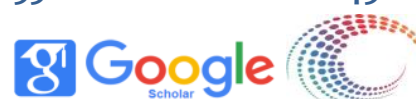

metapata

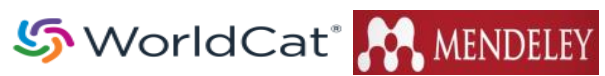

Publisher: Master Journals

At the same time, as the political leadership of the Republic noted, as a result of the mistakes made by the ministries of water economy and Agriculture of the Uzbekistan SSR and the irregularities in the water system, there is a shortage of water in some districts, and in some districts on the contrary, as a result of the abundance of water, the level of salinity of the lands increased, these lands were left out of use[2].

\section{THE MAIN FINDINGS AND RESULTS}

As a result of large-scale irrigation and melioration works carried out in the Uzbek SSR, by the end of 1940 the problem of water scarcity was solved in many cotton-growing regions of the Republic. As a result of the construction of new collectors and trenches and the repair of old ones, the problem of salinity of the Earth was significantly reduced[3].

At the same time, the task of mastering new lands in the Fergana Valley and carrying out irrigationmelioration work was also planned by the Union and the leadership of the Republic. To this end, the resettlement of the inhabitants of the Andijan, Namangan and Fergana regions of the valley to the Central Fergana lands, as well as the organization of new agriculture, as well as the acquisition of $\mathrm{New}$ Lands, was of great importance in the socio-economic life of the region and in the development of Agriculture.

According to the factors of the organization of the relocation policy, collective farm families with experience in the work of appropriation of new lands, like other regions, were displaced. In particular, from 1951 on the initiative of large collective farms of Central Fergana, several farm channels were excavated. In 1952, 2060 collective farmers from Andijan, Fergana and Namangan regions were transferred to the new lands of Central Fergana[4].
Thus, this process was actively carried out in the early 1950s, when its scope went back to the middle of the 1950 s and received a mass influx. Because, in 19561960 , it was planned to increase the crop fields on irrigated lands of Uzbekistan in the USSR by 380,7 thousand hectares and 187.8 thousand hectares on account of new lands appropriating the land. In order to determine the scale of relocation to collective farms, each farm was planned from 6 hectares of land, it was necessary to move 187,8 thousand families to master 31,1 thousand hectares of new land[5].

Relocation policy was established in the second half of 40 - ies of the XX century - 1950 years as an important economic and social event in the life of the Andijan region. At the same time, the issues of establishing the activities of newly created farms, their economic development and increasing labor efficiency were of great importance.

The displaced population was mainly derived from collective farms in the densely populated Andijan, Altynkul, Leninsk (now the city of Asaka) districts. The income of collective farmers in this district was high, as well as their private houses, farmhouses, gardens and cattle.

Analyzing the course of this process by the example of economic indicators of some collective farms in the region, one can see that this region reveals the development of newly created collective farms and some changes in the life of the population. In particular, on the example of the collective farm activity named after Kosigin of the Khaldivanbek Rayon (the village in the present Shahrichon district), this collective farm was established only in 1949 year on the account of the displaced population, the resettlement of its population began in 1950 and 57 farms were moved. Among them, the people worthy of Labor made up 118 people. To move the population of this 
CURRENT RESEARCH JOURNAL OF PEDAGOGICS

(ISSN -2767-3278)

VOLUME 03 ISSUE 01 Pages: 67-74

SJIF IMPACT FACTOR (2021: 5• 714)

OCLC - 1242041055 METADATA IF - 8.145
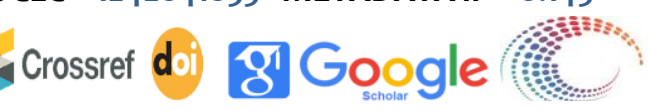

mETอDกTด

ST WorldCat 6 MENDELEY

Publisher: Master Journals

collective farm continued until 1955, in 195122 units, in 195215 units, in 195333 units, in 195429 units, in 1955 26 units, during these years a total of 182 families were moved, of which 372 people were worthy of Labor. But as a result of the unresolved nature of some social problems, as well as the unsatisfactory living conditions, 48 farms from the farms that had moved during these years had returned to their villages[6].

In order to solve the social problems of the displaced collective farmers, 967804 thousand soums were allocated by the leadership of the Republic and 96 houses were built during the years 1950-1954[7]. But, as already mentioned above, the number of families who moved to the collective farm named after Kosigin, in total, formed 182 families. It turns out that the problem of providing housing was not fully solved (the plan of housing for migrant families was executed even less than about 50\%) caused great difficultieschiliklar, as a result of which some of them left the collective farm, while the part that was not provided with housing was forced to live in basements for a certain period of time[8].

Also, in 1950-1955, in the "Kosigin" collective farm of the Andijan region of the Chaldivanbek district (the village in the present Shahrichon district), a cattlebreeding complex, cotton-drying and a club was built and put into operation. But the fact that social objects, which are very important, such as schools, hospitals or ambulances, are not equipped, is an indication that social mummies have not been solved in this collective farm. The reasons for the unresolved nature of these social problems were analyzed in detail in the next chapter of the study.

Analyzing the process of moving the population of the Andijan region in the Lenin district "komsomol" collective farm, one can see that even in this farm there are such problems as in the kosigin collective farm in the Khaldivanbek district. This collective farm was founded in 1954 by Boz rayonida, which allocated 578 hectares in 1954 and 571 hectares of arable land in 1955. In 1954, 80 farms were moved to this collective farm (165 of them were eligible for labor), in 195539 families (82 people were eligible for labor), all 119 families were moved for two years and 347 of them were eligible for Labor[10].

The establishment of the "Stalin road" collective farm in the Izboszkhan District of the Andijan region and the process of resettlement of the population to it and its activities are also confirmed by the following facts: this collective farm was established in 1953 in the reserve land "Ormonbek" of newly irrigated lands. In the same year, 67 families moved to this collective farm, of which 138 were eligible for Labor. And in the next year, the number of transplanted farms was much less, it was 29 units, and the number of labor-intensive population consisted of 61 people. And in 1955, 24 families moved, of which 52 were eligible for labor, and for three years Their, that is, the number of settlers made up 120[11].

Issues related to the implementation of the policy of relocation, the organization of new collective farms and their effectiveness, social problems of the people there, we will also consider the example of the collective farm "Malenkov", which was established in 1950 in the "Ormanbek" Massif. 286 families were moved to this collective farm in 1950-1955, 638 of them were worthy of Labor. But 207 of these families were settled, and the rest had returned to their villages.

In general, if we draw some general conclusions on the indicators of collective farms, in which the Andijan region was established in the first half of the 1950 years on new irrigation lands, that is, the above activities were analyzed, they consist of: 
CURRENT RESEARCH JOURNAL OF PEDAGOGICS

(ISSN -2767-3278)

VOLUME 03 ISSUE 01 Pages: 67-74

SJIF IMPACT FACTOR (2021: 5. 714)

OCLC - 1242041055 METADATA IF - 8.145
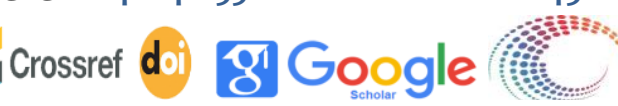

metapenta

5) WorldCat ${ }^{\circ}$ fी MENDELEY

Publisher: Master Journals

All these collective farms were moved by 695 families (with the exception of the returned farms), of which 1440 people were eligible for Labor[13].

Analysis of some aspects of the process of moving the population of the Andijan region to newly mastered lands shows that there were obstacles to its implementation. As difficult as this is primarily concerned with economic-financial and Human Factors. For example, according to the plan of internal resettlement of the population of the Andijan region on the basis of the resolution of the Soviet of Ministers of the USSR in 195528 janvar, 700 families were to be transferred to collective farms and 165 farms to the sovkhozs. On the basis of the above-mentioned decree of the government of the Republic, the committee of the oblast party approved the plan of relocation on February 2, 1955 and sent it to the districts, respectively, collective farms and Soviets[14].

In January 1955, a meeting was convened with representatives of the district councils and the newlyestablished collective farms to choose the displaced population. A seminar on this issue was also organized, in which Egorov, assistant to the chairman of the oblast Executive Committee, also took part.

Mass propaganda work was carried out with the participation of 34 new collective farms, district executive committees, district party committees, representatives of the district and oblast komsomol committees on the issue of preference and selection of displaced families in newly created farms for the population in the districts and collective farms. In addition, two Rayon instructors and responsible employees of the district executive committee were allocated from The Boz rayon party committee and a poster entitled "On Benefits" was distributed[15].
The process of relocation was widely covered in the gaskets of the region and the rayon, as well as radio broadcasts were used for this purpose. Also, the settlers invited the remaining relatives of their villages to the newly created collective farms, where they were told about the conditions and benefits created for them and the methods of persuading them to move were also used.

In the process of carrying out the plan of moving the population, obstacles were laid by some collective farm leaders. Despite the fact that they had a plan to be fulfilled, they did not want to give up the nomadic population or chose the people they encountered, and not the collective farmers who were capable of labor for emigration.

For example, such cases were allowed by the chairman of the "Telman" collective farm of the Oltinkul District of the deputies of the Supreme Soviet of the Uzbek SSR Yuldashev, the head of the "Stalin" collective farm of the "Yorbashi" village Soviet of the Andijan district Bakirov and others. Chairman of the Presidium of the Supreme Soviet of the USSR of Uzbekistan After sending a letter to Sh. R. Rashidov, these shortcomings were eliminated as a result of the intervention of the leaders of the oblast Executive Committee and the oblast party committee [16].

The process of relocation began in January 1955 year, but due to the non-availability of roads, and in February the precipitation of chronic rain, this process was completed in may and the following results were achieved in this year:

According to the plan, 700 families had to be moved, but 833 families were moved and $119 \%$ of the task was completed. The displaced families consisted of 3706 people, of whom 1882 were eligible for Labor[17]. 
CURRENT RESEARCH JOURNAL OF PEDAGOGICS

(ISSN -2767-3278)

VOLUME 03 ISSUE 01 Pages: 67-74

SJIF IMPACT FACTOR (2021: 5• 714)

OCLC - 1242041055 METADATA IF - 8.145
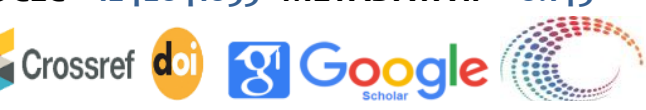

mETอDกTด

S. WorldCat 6 MENDELEY

Publisher: Master Journals

477 families from 833 displaced families were involved in the resettlement of districts, while domestic relocation, that is, the resettlement of districts in their territories, constituted 356 families. The social and economic activity of the displaced was confirmed by the following factors: each displaced family consisted of an average of 4.2 members, of whom 2.2 were eligible for Labor. The number of tractors was 23 units, farms with their own livestock were 84 units, while 197 families were given loans.

For the party and Soviet authorities, the issues of their membership in the party and Komsomol were also controlled, since not only the social situation of the displaced population, but also their partiality was important. For example, among the total displaced farms were families consisting of 23 party members and 75 komsomol members[18].

At the beginning of the plan for moving to Soviets in 1955 year there were 165 families, but on the basis of the decision of the Ministry of Soviets of the Republic on July 24, 1955 this plan was reduced to 30, the relocation of 135 farms was determined and this task was $100 \%$ fulfilled.

As noted above, the resettlement of the population of this region to newly mastered lands was carried out on the account of the resettlement of the population living in collective farms with a large number of inhabitants of the Boz and Balikchi districts, which are adjacent to the Central Ferghana. In general, as a result of the serious shortcomings allowed in the process of relocation in the region, a large part of the displaced population abandoned newly created farms and again returned to their former habitat.

For example, such a negative case appeared in the region in 1950-1952 years with the following appearance. In 1950, 947 farms were moved, 577 of them, 908 families were moved in 1951, 487 of them and 1089 farms were moved in 1952, 471 of them left the newly established collective farms. Thus, for three years, all 2944 farms were transferred to collective farms, which were established on newly mastered lands, of which 1534 had left their farms, where they moved[19].

As can be seen from the data, for three years, more than $50 \%$ of the population displaced in the oblast left the newly formed collective farms, and this policy did not justify itself both economically and politically. Because it was a huge expenditure by the state on the resettlement of the population to new places, as well as the departure of a large part of the displaced population, the success of this process carried out by the government was questionable.

On the example of some collective farms, the abandonment of newly formed collective farms by the displaced population was mainly due to the fact that social problems, in the first place, did not provide housing. At the same time, as in the Fergana region, Andijan, the relocation department has often taken people who have faced the challenge of relocating their population to newly mastered lands, that is, people who have a tendency to relocate without comprehensively studying, which is also the reason that they are organized only on the basis of their desires. Also, the displaced population is not interested in the benefits that will be given to them.

Thus, according to the above-mentioned evidence, the following conclusion can be drawn: the policy of resettlement of the population of the Andijan region in the first half of the 1950 s was one of the important events in the socio-economic life not only in the region, but also in the Fergana Valley and the Uzbek SSR, and this process was aimed At the same time, this process has become an important part of the state policy aimed 
CURRENT RESEARCH JOURNAL OF PEDAGOGICS

(ISSN -2767-3278)

VOLUME 03 ISSUE 01 Pages: 67-74

SJIF IMPACT FACTOR (2021: 5. 714)

OCLC - 1242041055 METADATA IF - 8.145
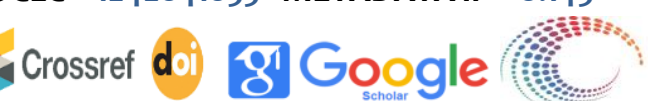

metapata

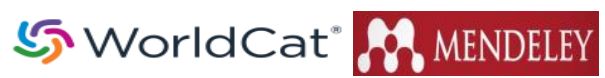

Publisher: Master Journals

at solving the social problems of the people of the region and ensuring the social mobilization of the population.

Also, the second half of the 1940 - the migration policy carried out on the scale of the USSR from the 1950s-was one of the important directions of the socioeconomic policy of the Soviet government, which led to the socio-economic development of the villages of Uzbekistan, including the Fergana Valley regions, in particular, the increase in cotton production, as well as the.

In the Andijan region, the process of relocation of the population was carried out at an accelerated pace in the second half of the 1950s, like other regions of the Fergana Valley.

In 1957, new collective farms appeared on the basis of the migrated population, such as the Namangan and Fergana regions of the Fergana Valley, in the Andijan region. Five new collective farms were created on the account of the population displaced in the reserve lands" sarikjuga "and" Ulugnor". They consisted of "communism" in Andijan district, "Lenin Road" in Bulgbashi District, "Red Star" in Khujaabad district, "Khrushchev" in Kholduvonbek district and finally "Gulistan" in Chinabad district. Newly established collective farms received 4648 thousand soums of money, 186 cattle, 48 horses, 311 sheep, etc.from the main collective farms (new collective farms were established on the basis of these farms)[20].

In general, in the Andijan region in 1957, the transfer of the population to the newly created collective farms and Sovkhoz was successfully carried out, the plan was fulfilled by $148 \%$. The plan of relocation of the population in the districts of Khalduvonbek, Lenin, Altynkul and Andijan was not fulfilled at all, if such a rayon as Bunda Izkankan, Stalin, Kurgantepa, Boz, Khodzhaabad was well organized[21].

During the period from December 1, 1957 (according to the eleven months of the year) in the process of moving the population, 668 families, including 2871 people were displaced, 1455 of whom were worthy of labor, instead of 550 people in the plan. On the scale of One District, 321 (60\%) farms, and 142 (25\%) families were moved from collective farms with less land reserves to farms with more land reserves. Of these, the farm up to 50 soles received 12 collective farms, and the family from 50 to 100 soles received 3 collective farms[22].

It is worth noting that this year in the Andijan region the process of moving the population to the region, that is, to the Mirzachul massif of the Tashkent region was also carried out. But the situation in this direction is different from internal displacement, and the plan of moving the region has not been fulfilled. Instead of 1000 farms in the plan, 701 farms were moved, of which 512 (86 \%) were moved to the new sovkhozes established here, while 189 (70,1\%) were moved to the collective farms. The main reasons for the failure of the relocation plan by regions were the lack of readiness to accept the resettled population of these new collective farms and Soviets, and the second was the frequent change of relocation addresses.

Due to the inadequacies allowed in the campaign for relocation in the region, a part of the population again caused them to leave their farms. For example, according to the statistics of the population who left the newly created farms in 1955-1957, according to the statistics of the population who left the newly created farms in 1955, the total number of families who left the newly created farms in 1955 was $17.3 \%$ of the population who moved, while in 1956 this figure made up 19 families And in 1957 year, the families that left the 
CURRENT RESEARCH JOURNAL OF PEDAGOGICS

(ISSN -2767-3278)

VOLUME 03 ISSUE 01 Pages: 67-74

SJIF IMPACT FACTOR (2021: 5• 714)

OCLC - 1242041055 METADATA IF - 8.145
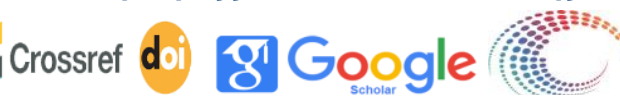

METลDดTล

S WorldCat Wh MENDELEY

Publisher: Master Journals

new farms were only 7 units, which was equal to $0,8 \%$ of all farms that moved.

At the cross-section of the districts, this indicator appeared as follows: the departure of the displaced population from the new farms was observed Bozsuv rayonida, which in 1955 constituted 64 families, in 195610 families and in 1957-2 families. Also, the newlyestablished farms in the Pakhtaabad district were abandoned in 1955 year by 16 families, in 1956 year by only one family, all the families who moved in 1957 year were settled[23].

Even among the population who abandoned the new farms, as a result of certain propaganda work, a part of the 170 farms that went away for three years, that is, 73 of them returned again, but 97 families remained in their old farms in general.

Considering the process of the departure of the displaced population from newly created farms in the years 1950-1952 (1534 families) and 1955-1957 (170 families), the rate of departure among the displaced population was sharply reduced as a result of the elimination of many shortcomings in the later stages of migration, as well as the resolution of the social problems of the This was certainly one of the achievements in the relocation campaign.

\section{CONCLUSION}

According to the above evidence, there was a certain difference in the internal and External (by regions) migration of the population of the region. If in internal migration, the farms were mainly moved to collective farms, then in the process of external migration, a large part of the families were transferred to sovkhozes.

The relocation of the population to newly assimilated lands was also carried out in the first half of the 1960 s. The campaign for the resettlement of the population carried out in these years was much more orderly and systematic than the previous ones, ensuring that the economic and social results of the resettlement campaign were relatively positive.

\section{REFERENCES}

1. Ходжиев Э. Х. История орошения и освоения Голодной степи... - С. 137.

2. Коммунистическая партия Узбекистана в резолюциях и решениях съездов и пленумов ЦК. Том второй... - С. 359.

3. Коммунистическая партия Узбекистана в резолюциях и решениях съездов и пленумов ЦК. Том второй. - С. 353.

4. Очилов Н. Ўзбекистонда ирригациямелиорация ишлари... -Б.29.

5. Коммунистическая партия Узбекистана в резолюциях и решениях съездов и пленумов ЦК. Том второй. - С. 354.

6. UzRMA. Fund 2347, List 1, Case 30, Sheet 168.

7. Source above ... Page 167.

8. UzRMA. Fund 2347, List 1, Case 30, Sheet 168.

9. Source above ... Page 167.

10. Source above ... Page 169.

11. Source above ... page 171.

12. UzRMA. Fund 2347, List 1, Case 30, Sheet 173.

13. Source above .... page 174 .

14. Source above .... page 192.

15. UZRMA. Fund 2347, List 1, Case 30, Sheet 192.

16. Source above ... page 193.

17. UZRMA. Fund 2347, List 1, Case 30, Sheet 193.

18. Source above ... Page 194.

19. UzRMA. Fund 2347, List 1, Work 30, Sheet 20.

20. UzRMA. Fund 2347, List 1, Case 49, Sheet 214.

21. Source above ... page 215.

22. UzRMA. Fund 2347, List 1, Case 49, Sheet 215.

23. UzRMA. Fund 2347, List 1, Case 49, Sheet 241. 
CURRENT RESEARCH JOURNAL OF PEDAGOGICS

(ISSN -2767-3278)

VOLUME 03 ISSUE 01 Pages: 67-74

SJIF IMPACT FACTOR (2021: 5. 714)

OCLC-1242041055 METADATA IF - 8.145

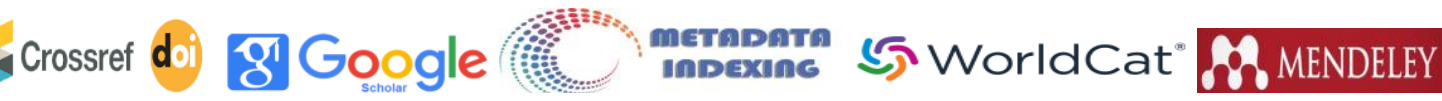

Publisher: Master Journals

24. Kodirov N. Problems of the globalization of information culture in the current time //Ştiință, educație, cultură. - 2020. - T. 4. - C. 272-274

25. Nodirbek Kodirov Mamasoliyevich. (2021). Current issues of formation of information culture in youth.

https://doi.org/10.5281/zenodo.5770626 